Семенцов В. I.

Командно-штабний інститут застосування військ (сил) Національного університету оборони України імені Івана Черняховського, Київ

\title{
Перспективи розвитку берегових ракетно-артилерійських військ Військово-Морських Сил, озброєних береговими рухомими протикорабельними ракетними комплексами
}

Резюме. Розглядаються перспективи розвитку берегових ракетно-артилерійських військ та можливість виконання завдань ВМС ЗС України щодо посилення оборони за допомогою застосування перспективних берегових рухомих протикорабельних ракетних комплексів.

Ключові слова: берегові ракетно-артилерійські війська; береговий рухомий протикорабельний ракетний комплекс; Військово-Морські Сили; протикорабельні ракети.

Постановка проблеми. В умовах протистояння у збройній боротьбі проти російської агресії на Сході України та намагання військового керівництва Збройних Сил України розв'язати питання протидесантної оборони в Азовській операційній зоні Військово-Морськими Силами Збройних Сил України були прийняті на озброєння артилерійські системи 2А-36 “Гіацинт-Б” і Д-20 (калібр - 152 мм) [13], якими були укомплектовані військові частини та підрозділи берегових ракетноартилерійських військ Військово-Морських Сил (БРАВ ВМС) Збройних Сил (ЗС) України [1-5].

Актуальність теми, що розглядається, полягає у потребі виконання основних завдань щодо оборони морського узбережжя, військово-морських баз і пунктів базування ВMC ЗС України, портів, берегової інфраструктури цивільного та військового призначення нашої держави, а також забезпечення iii економічних інтересів у територіальних водах $\mathrm{i}$ поблизу них. Неможливість досягнення цієї мети наявними силами й засобами в умовах відсутності достатнього фінансування на розвиток надводних кораблів і підводних човнів потребує вжити відповідні заходи щодо посилення оборони іншими доступними засобами [1-6].

Аналіз останніх досліджень i публікацій. У роботах $[8,10-13]$ вітчизняними та закордонними фахівцями розглядались питання організації оборони держави 3 морського напрямку та застосування берегових рухомих протикорабельних ракетних комплексів, але ці питання потребують детальнішого розгляду 3 урахуванням практичного досвіду, якій набули БРАВ ВМС під час ведення Антитерористичної операції на сході нашої держави.
У роботах $[5,6]$ частково представлені проблемні питання оборони свого узбережжя. Проте в межах проаналізованих джерел зміст критичних ситуацій не розкрито повною мірою щодо Сходу України, де нині виконують свої службові обов'язки військовослужбовці ВМС ЗС України.

Метою статті є розгляд перспективних шляхів розвитку БРАВ ВМС ЗС України, озброєних перспективними береговими рухомими протикорабельними ракетними комплексами.

Виклад основного матеріалу. Використання на сьогодні БРАВ ВМС 3 артилерійськими системами, які не пристосовані для ведення вогню по морських поодиноких цілях, а призначені в основному для подавлення та знищення наземних об'єктів і підтримання військ на сухопутному напрямку [12-13], не сприяє виконанню поставлених завдань.

На початок війни 2014 року це був вимушений захід, але проблема полягає в тому, що берегові артилерійські системи БРАВ ВMC, які використовувалися в радянські часи і використовуються натепер [7-10] пристосовані для ведення вогню по морських одиночних рухомих цілях завдяки наявності радіолокаційних станцій спостереження, які спроможні виявляти цілі на морській поверхні, супроводжувати їx, фіксувати сплески від падіння снарядів у воду, вводити необхідні коректури за допомогою автоматичних приладів управління стрільбою для наведення артилерійських систем та влучного ведення стрільби.

Для виконання покладених на ВМС 3С України завдань - на сьогодні кораблі ВМС ЗС України, не маючи протикорабельних ракет (ПКР), не в змозі самостійно протистояти кораблям країни-агресора - необхідно терміново переглянути пріоритети розвитку 
ударного озброєння і задіяти сучасні ПКР, а також самохідні пускові установки у складі берегових рухомих протикорабельних ракетних комплексів (БРПРК) вітчизняного виробництва.

На озброєння у провідних країнах світу прийняті сучасні протикорабельні ракети, аналогом яких в України на цей час $є$ ПКР "Нептун".

Випробування розробленої нової ПКР "Нептун" було проведено у Київському державному конструкторському бюро “Луч" у квітні 2019 року, а прийняття на озброєння планується в 2020-2021 роках. Протикорабельна крилата ракета конструктивно розміщується у транспортному пусковому контейнері й може виробляться у варіантах морського, повітряного або наземного базування та дає певний шанс вирішення названих завдань ВМС ЗС України.

Розглянемо перспективу застосування сучасних берегових рухомих протикорабельних ракетних комплексів (БРПРК) $з$ ракетою українського виробництва "Нептун" (рис. 1). Виробництво перспективного ракетного озброєння відбувається при кооперації 3 іншими українськими підприємствами, зокрема 3 Харківським авіаційним заводом, підприємством “Мотор Січ” та іншими [10-12]. ПКР "Нептун" за своїми можливостями аналогічна за конструкцією до російської протикорабельної ракети Х-35 зі складу комплексу “Бал-E” [6]. Порівняння 3 іншими аналогами наведено у табл. 1.

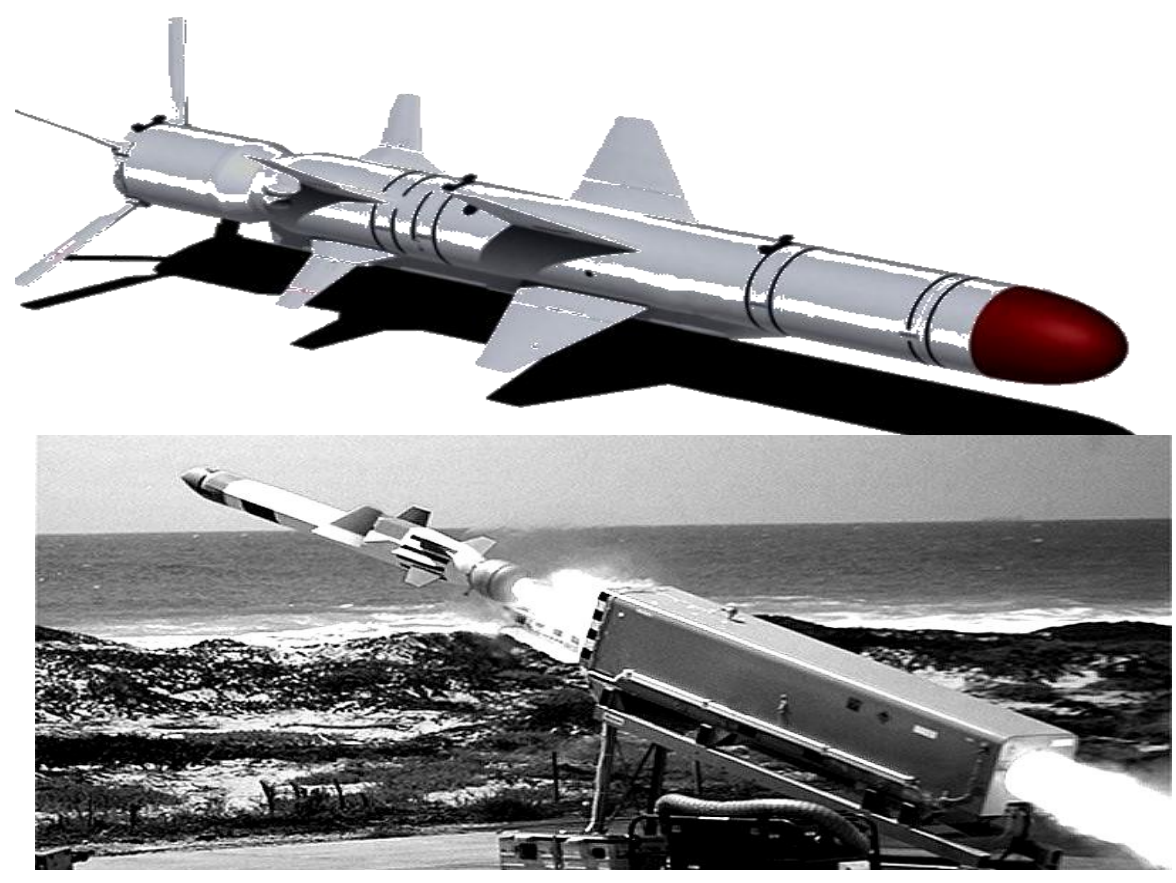

Рис. 1. Перспективна українська ПКР “Нептун”

Таблиця 1

Основні ТТХ ПКР “Нептун” у порівнянні з аналогами

\begin{tabular}{|c|c|c|c|c|}
\hline Параметри & Ракета "Нептун" & Ракета X-35 (2003) & Ракета X-35У (2015) & Ракета "Гарпун" D2 \\
\hline Дальність & До 300 км & До 130 км & До 260 км & До $280 \mathrm{\kappa м}$ \\
\hline Вага & 870 кг & 600 кг & 670 кг & 742 кг \\
\hline $\begin{array}{l}\text { Вага бойової } \\
\text { частини }\end{array}$ & 150 кг & 145 кг & 145 кг & 235 кг \\
\hline Калібр & 380 мм & 420 мм & $420 \mathrm{MM}$ & 340 мм \\
\hline Довжина & $5,05 \mathrm{M}$ & $4,40 \mathrm{M}$ & $4,40 \mathrm{M}$ & $5,18 \mathrm{M}$ \\
\hline $\begin{array}{l}\text { Наведення } \\
\text { (на марші) }\end{array}$ & $\begin{array}{c}\text { Iнерційне } 3 \text { GPS } \\
\text { корекцією } \\
\end{array}$ & Інерційне & $\begin{array}{c}\text { Інерційне з ГЛОНАС } \\
\text { корекцією } \\
\end{array}$ & $\begin{array}{c}\text { Iнерційне } 3 \text { GPS } \\
\text { корекцією } \\
\end{array}$ \\
\hline $\begin{array}{l}\text { Наведення } \\
\text { (наприкінці } \\
\text { маршруту) } \\
\end{array}$ & $\begin{array}{c}\text { Активна } \\
\text { радіолокаційна ГСН }\end{array}$ & $\begin{array}{c}\text { Активна } \\
\text { радіолокаційна ГСН }\end{array}$ & $\begin{array}{l}\text { Активна та пасивна } \\
\text { радіолокаційна ГСН }\end{array}$ & $\begin{array}{c}\text { Активна } \\
\text { радіолокаційна ГСН }\end{array}$ \\
\hline $\begin{array}{l}\text { Атака } \\
\text { наземних } \\
\text { цілей }\end{array}$ & Проводиться & Не проводиться & Проводиться & Проводиться \\
\hline
\end{tabular}

Крилата ракета "Нептун” [10-12] призначена для ураження бойових надводних 
кораблів і транспортних суден зі складу ударних груп (конвоїв) або поодиноких, водотоннажністю до 5 тис. т, в умовах активної вогневої і радіоелектронної протидії.

Відомо [8], що швидкість ракети декілька нижче звукової, вона $є$ дозвукова, заявлена дальність польоту до 280 км, довжина самої ракети з прискорювачем - 5050 м, маса приблизно 850 кг. Перспективна ракета розміщується у транспортно-пусковому контейнерах 3 розмірами $5300 \times 600 \times 600$ мм. Транспортно-пускові контейнери 3 ракетою 3 хрестоподібним складним крилом можуть розміщуватися на наземних, морських або повітряних носіях.

На сьогодні ВМС України не здатні припинити ворожі дії у своїх територіальних водах та узбережжі лише силами надводних кораблів. Використання неприкритих мінних полів i бонових сіткових загороджень $\epsilon$ малоефективним. Крім того, втрачена значна кількість комплектів морських мін у Севастополі. Для скорішого поліпшення ситуації в найближчі строки залишається застосування берегових протикорабельних ракетних комплексів (передусім - рухомих), оснащених перспективною сучасною власною ПКР "Нептун”.

Розміщення стартових позицій БРПРК у районі міст Маріуполь і Бердянськ (рис. 2) може створити серйозну протидію надводним кораблям країни-агресора в Азовській операційній зоні. Наявність ще двох стартових позицій БРПРК у районі м. Нова Каховка та м. Сарата забезпечить мінімально-достатній варіант розгортання БРПРК на узбережжі Чорного моря, який примусить командування ЧФ РФ відмовитись від виконання поставлених завдань щодо висадки десанту, ураження об'єктів берегової інфраструктури основними штатними засобами, демонстрації військової сили тощо.

Під час практичної реалізації програми розбудови українських БРПРК можуть бути виявлені й інші економічні та оперативнотактичні переваги.

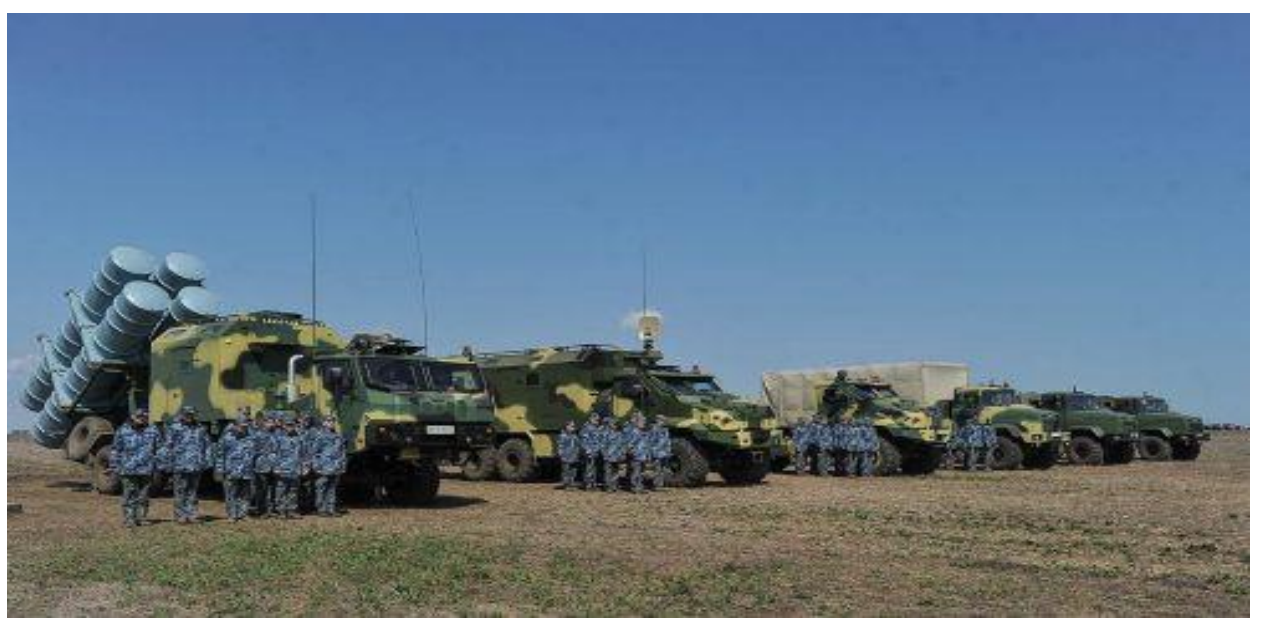

Рис. 2. Береговий рухомий протикорабельний ракетний комплекс з ПКР “Нептун”

У перспективі після прийняття на озброєння берегового рухомого протикорабельного ракетного комплексу 3 протикорабельною крилатою ракетою "Нептун" вітчизняного виробництва доцільно продовжити розроблення новітніх артилерійських систем на рухомій базі за принципом артилерійського комплексу А-222 "Берег” [8, 10, 14], який за своїм призначенням відповідає поставленим завданням - ураженню надводних морських поодиноких швидкісних цілій. Тільки у взаємодії двох взаємопов'язаних між собою систем ураження морських цілей (артилерія веде вогонь щодо знищення цілей у прибережній зоні, яка $€$ “мертвою” для можливості ураження в ній цілей ракетами), можливо значно підвищити ефективність застосування БРАВ ВМС.
Висновки. Наявність двох-трьох берегових рухомих ракетних дивізіонів у складі БРАВ (рис. 2), а на перспективу ракетної бригади, які діятимуть у Чорноморській та Азовській операційних зонах, озброєних сучасними береговими рухомими протикорабельними ракетними комплексами 3 протикорабельною крилатою ракетою вітчизняного виробництва, надасть перспективу для подальшого розвитку берегових ракетно-артилерійських військ Військово-Морських Сил та значно підвищить оборонні спроможності ВМС 3С України.

Як наслідок, за допомогою запропонованого підходу розкривається перспектива розвитку БРАВ ВМС та можливість ефективного виконання завдань ВМС 3С України загалом. 
Подальші дослідження у цій галузі доцільно присвятити розробленню математичної моделі та використанню іiі для обгрунтування перспективного складу БРАВ 3 перспективними зразками озброєння ВМС ЗС України.

Матеріал, викладений у статті, доцільно використовувати під час обгрунтування шляхів розвитку БРАВ озброєних сучасними береговими рухомими протикорабельними ракетними комплексами, а також набуття спроможностей та бойової ефективності БРАВ ВМС ЗС України.

\section{СПИСОК ВИКОРИСТАНОЇ ЛІТЕРАТУРИ}

1. Державна цільова оборонна програма розвитку ОВТ Збройних Сил України на період до 2022 року, (в ред. Постанови Кабінету Міністрів України від 29 серпня 2018 року.

2. Державна програма розвитку Збройних Сил України на період до 2020 року, затверджена Указом Президента України від 22 березня 2017 року №73/2017.

3. Концепція розвитку сектору безпеки і оборони України, затверджена Указом Президента України від 14 березня 2016 року №92/2016.

4. Доктрина застосування сил оборони держави, затверджена наказом Верховного Головнокомандувача Збройних Сил України від 17 серпня 2018 року № 20.
5. Морська доктрина України на період до 2035 року, затверджена Постановою Кабінету Міністрів України від 7 жовтня 2009 року № 1307. 6. Морська стратегія держави. Розвиток та реалізація морського потенціалу України : матеріали міжнародного наукового форуму, 24-25 травня 2016 року. Київ : Національний університет оборони України імені Івана Черняховського, 2016. $216 \mathrm{c}$.

7. Боевые возможности ВМФ РФ и ВМС США 2015. URL: http://flot.com/nowadays/ structure /techreadiness /2015.

8. Дончак А. М., Дубов О. В., Петровський О. Г. Деякі питання формалізації морського бою корабельних ударних груп (кораблів) ВМС 3С України. Збірник наукових пращь Військової академії. Одеса, 2016. Вип. 3 (5). С. 88-103.

9. Довідник учасника АТО : озброєння і військова техніка Збройних сил Російської Федерації / А. М. Алімпієв, Г. В. Пєвцов, Д. А. Гриб та ін. ; за заг. ред. А. М. Алімпієва. Х. : Оригінал. 732 с.

10. Мрії Києва - українські крилаті ракети. URL: http://vesna-info.ru/ukraine/5051-mechty-kievaukrainskie-krylatye-rakety. html.

11. 10.03.2016. В Україні випробують новітню суперракету. URL: http://socportal.info/2016/03/10/vukrayini-viprobuyu t-novitnyu-superraketu.html.

12. Артилерійські системи 2А36 Гіацинт, Д-20. URL: https://uk.wikipedia.org.

13. Артилерійська зброя. URL: https://armyman.info/ oruzhie-flota/morskaya-artilleriya.

Стаття надійшла до редакції 26.09.2019

Семенцов В. И.

Кафедра Военно-Морских Сил командно-штабного института применения войск (сил) Национального университета обороны Украины имени Ивана Черняховского, Киев.

Перспективы развития береговых ракетно-артиллерийских войск ВоенноМорских Сил вооруженных береговыми подвижными противокорабельными ракетными комплексами

Резюме. Рассматриваются перспективы развития береговых ракетно-артиллерийских войск и возможность выполнения ими задач Военно-Морских Сил Вооруженных Сил Украины для укрепления обороны путем применения перспективных береговых подвижных противокорабельных ракетных комплексов.

Ключевые слова: береговые ракетно-артиллерийские войска; береговой подвижный противокорабельный ракетный комплекс; Военно-Морские Силы; противокорабельные ракеты.

\section{Sementsov}

Department of the Naval Forces of the command and staff institute for the use of troops (forces) of the National University of Defense of Ukraine named after Ivan Chernyakhovskyi, Kiev

Prospects of development of coastal rocket-artillery troops of Naval Forces of armed by coastal movable протикорабельними rocket complexes

Resume. The prospects of the development of coastal missile and artillery troops, their fulfillment of the tasks of the Naval Forces of the Armed Forces of Ukraine to strengthen defense through the use of promising coastal mobile anti-ship missile systems are considered. missiles.

Keywords: coastal rocket-artillery troops; coastal mobile anti-ship missile system; Naval Forces; anti-ship 